\title{
COORDINATION COMPOUNDS OF Cu (II) AND Ni (II) WITH SCHIFF BASES DERIVED FROM FORMYLMENTHONE AND AROMATIC AMINES
}

\author{
Christina Marie Zalaru루, Florica Zalaru², Adalgiza Ciobanu' ${ }^{1}$, Maria Marinescu ${ }^{1}$, Anca Daniela \\ Raiciur $^{3,4 *}$ \\ ${ }^{1}$ University of Bucharest, Faculty of Chemistry, Department of Organic Chemistry, Biochemistry and Catalysis, 90- \\ 92 Panduri Road, Bucharest Romania, \\ ${ }^{2}$ University of Bucharest, Faculty of Chemistry, Department of Inorganic Chemistry, 23 Dumbrava Roşie, Bucharest \\ Romania \\ ${ }^{3 *}$ Hofigal Export-Import S.A.,Intrarea Serelor street,no.2,district 4,Bucharest,Romania \\ $4^{4}$ University of "TITU MAIORESCU", Faculty of Pharmacy, Department of Pharmacognosy, Phytochemistry, \\ Phytoterapy, Gh. Sincai Street, no.16, 4 district, cod. 040 313, Bucharest, Romania \\ *Correspondence e-mail:daniela_raiciu@yahoo.com
}

\begin{abstract}
The Schiff bases obtained from formylmenthone and o-, m-, p-toluidine behave as bidentate ligands with $\mathrm{O}$ and $\mathrm{N}$ donor atoms in $\mathrm{Ni}(\mathrm{ll})$ and $\mathrm{Cu}(\mathrm{II})$ complexes by the type $\mathrm{NiL}_{2}$ and $\mathrm{CuL}_{2}$. $\left(\mathrm{H}_{2} \mathrm{O}_{2}\right.$. The donor atoms and the possible geometry for the complexes were assigned by means of chemical, thermodifferential analyses and electronic, EPR and IR spectra.
\end{abstract}

Keywords: formylmenthone, complexes, synthesis, thermodifferential analyses, EPR, IR

\section{Introduction}

Terpenes represent the largest class of secondary plant metabolites, being used for antimicrobial activity. Terpenes act on gram-positive bacteria, less than gram-negative bacteria. [1] Monoterpenoids with nitrogen atoms, generally oxymes, or amines have various biological properties, such as anticancer [2], antimicrobial [3], antiviral [4].

A series of Schiff bases of menthone with aromatic amines has been synthesized and were evaluated for anticonvulsant activity. [5, 6]

Our previous paper [7] has reported the preparation and characterization of the coordination compounds of some "3d" metals with Schiff bases derived from 3-formylmenthone and aromatic amines. The position of the methyl substituent on the benzene ring has determined the type of the complex and monodentate or bidentate coordination of the ligands. It seemed desirable to investigate the coordination ability of the Schiff bases derived from 2-formylmenthone and o-, m-, p-toluidine on the same " $3 \mathrm{~d}$ " metals, for purposes of comparison.

\section{Materials and Methods}

\subsection{Materials}

$\mathrm{Cu}(\mathrm{CH} 3 \mathrm{COO})_{2 .} \mathrm{H}_{2} \mathrm{O}$ and $\mathrm{Ni}\left(\mathrm{CH}_{3} \mathrm{COO}\right)_{2} \cdot 4 \mathrm{H}_{2} \mathrm{O}$ p.a. Merck were used.

The syntheses were carried out using reagents and solvents of the highest quality of analytical reagent grade and were used without further purification. Distilled water was used in all experiments.

\subsection{Characterization Techniques}


The electronic diffuse reflectance spectra within 300-1100 nm range were obtained with VSU-2P Zeiss-Jena Spectrophotometer, using $\mathrm{MgO}$ as a standard.

EPR spectra were recorded at room temperature on polycrystalline powders, on ART-5-IFA Spectrograph.

The klystron frequency was $9060 \mathrm{MHz}$ and modulation of the magnetic field $100 \mathrm{KHz}$. The EPR spectral parameters were calculated against a Mn (1l) standard.

Thermodifferential analyses were carried out with a Paulik-Paulik-Erdey Derivatograph Q 1500D MOM. Conditions of measurements: temperature range up $1000^{\circ} \mathrm{C}$, heating program: $10 \mathrm{degree} / \mathrm{min}$, sensitivity DTA $=1 / 10, \mathrm{~m}_{4}=0.0180 \mathrm{~g}, \mathrm{~S}=20$ and $\mathrm{m}_{5}=0.0372 \mathrm{~g}$, $\mathrm{S}=50$; atmosphere over sample air.

IR spectra (KBr pellets) were measured on a BIO-RAD FTS-135 Spectrometer.

\subsection{Synthesis}

\subsubsection{General synthesis of ligands}

$0.01 \mathrm{~mol}$ formylmenthone was dissolved in $200 \mathrm{~mL}$ ethylic alcohol. A solution of toluidine dissolved in $40 \mathrm{~mL}$ ethyl alcohol is added in hot drop in the reaction mixture, after which it is maintained at the room temperature for 50 hours.

2.3.1.1.Synthesis of 6-isopropyl-3-methyl-2-[(2'-methylphenylamino) methylen]cyclohexan-1-one (ortho-L) (3a)

Compound 3a was synthesized according to general procedure of the ligands.

The crystals were filtered off, washed with water and dried in air; $1.39 \mathrm{~g}$ Yield (51\%); red-brown crystals; m.p. $=135^{\circ} \mathrm{C}$; IR (KBr, cm-1): 3200-3320 (m, vo-H), 1700 (sh, vc=o ), 1550, 1590, 1630 (vs, vc=N).

2.3.1.2.Synthesis of 6-isopropyl-3-methyl-2-[(3'-methylphenylamino) methylen]cyclohexan-1-one (metha-L) (3b)

Compound $\mathbf{3} \mathbf{b}$ was synthesized according to general procedure of the ligands.

The crystals were filtered off, washed with water and dried in air; $1.17 \mathrm{~g}$ Yield (43\%); brick-red crystals; m.p. $=105^{\circ} \mathrm{C}$; IR ( $\left.\mathrm{KBr}, \mathrm{cm}^{-1}\right)$ : 3310-3450 (m, vo-H), 1700 (vw, vc=o), 1560, 1620, 1640 (s, vc=N).

2.3.1.3.Synthesis of 6-isopropyl-3-methyl-2-[(2'-methylphenylamino) methylen]cyclohexan-1-one (para-L) (3c)

Compound $3 \mathrm{c}$ was synthesized according to general procedure of the ligands.

The crystals were filtered off, washed with water and dried in air.: $1.47 \mathrm{~g}$ Yield (54\%); red-brown crystals; m.p. $=110^{\circ} \mathrm{C}$; IR $\left(\mathrm{KBr}, \mathrm{cm}^{-1}\right): 3300-3400\left(\mathrm{~m}, v_{\mathrm{O}-\mathrm{H}}\right), 1700$ (vw, vc=o), 1520, 1580, 1630 (s, vc=N).

\subsubsection{General synthesis of the complexes}

The complexes were prepared by mixing warm aqueous methanol solution $(50 \%)$ of metal acetate $(1 \mathrm{mmol})$ and ligands $(2 \mathrm{mmols})$. The resulting precipitates were filtered and washed with aqueous methanol solution $(50 \%)$ and dried at room temperature. The metal content was obtained gravimetrically.

2.3.2.1. Synthesis of $\mathrm{Cu}$ (ortho- $\mathrm{L})_{2} .\left(\mathrm{H}_{2} \mathrm{O}\right)_{2}(5 \mathbf{a})$

Compound 5a was synthesized according to general procedure of the complexes. 
After the cooling at the room temperature, the pale green crystals were filtered off, washed with water and dried in air; 0.64 g Yield: $(20 \%)$. IR ( $\left.\mathrm{KBr}, \mathrm{cm}^{-1}\right): 3423$ (s, vo-H), 1558 (vs, vc=N), 1615(vs, vc=N), 1111 ( $w, \mathrm{H}_{2} \mathrm{O}$ coord.). Elemental analysis data calculated for $\mathrm{Cu}$ (ortho- $\left.\mathrm{L}\right) 2 .\left(\mathrm{H}_{2} \mathrm{O}\right)_{2}: \mathrm{Cu} 9.94 \%, \mathrm{H}_{2} \mathrm{O} 5.63 \%$. Found: $\mathrm{Cu} 10.37 \%, \mathrm{H}_{2} \mathrm{O} 7.03 \%$.

\subsubsection{Synthesis of $\mathrm{Cu}$ (metha- $\mathrm{L})_{2} .\left(\mathrm{H}_{2} \mathrm{O}\right)_{2}(5 \mathbf{b})$}

Compound $\mathbf{5 b}$ was synthesized according to general procedure of the complexes.

After the cooling at the room temperature, the blue crystals were filtered off, washed with water and dried in air; $0.54 \mathrm{~g}$ Yield: (17\%). IR (KBr, cm $\left.{ }^{-1}\right)$ : 3395 (m, vo-H), 1557 (s, vc=N), 1610(vs, vc=N), 1094 (w, $\mathrm{H}_{2} \mathrm{O}$ coord.). Elemental analysis data calculated for $\mathrm{Cu}$ (metha- $\left.\mathrm{L}\right)_{2}$. $\left(\mathrm{H}_{2} \mathrm{O}\right)_{2}: \mathrm{Cu} 9.94 \%, \mathrm{H}_{2} \mathrm{O} 5.63 \%$. Found: $\mathrm{Cu} 9.64 \%, \mathrm{H}_{2} \mathrm{O} 6.80 \%$.

\subsubsection{Synthesis of $\mathrm{Cu}$ (para- $\mathrm{L})_{2} .\left(\mathrm{H}_{2} \mathrm{O}\right)_{2}(5 \mathrm{c})$}

Compound $5 \mathrm{c}$ was synthesized according to general procedure of the complexes.

After the cooling at the room temperature, the gray crystals were filtered off, washed with water and dried in air; 0.76 g Yield: (24\%). IR (KBr, cm $\left.{ }^{-1}\right): 3399$ (m, vo-H), 1514 (vs, vc=N), 1545 (s, vc=N), 1613 (s, $\left.v_{c}=\mathrm{N}\right), 1111$ ( $\mathrm{w}, \mathrm{H}_{2} \mathrm{O}$ coord.). Elemental analysis data calculated for $\mathrm{Cu}$ (metha- $\left.\mathrm{L}\right)_{2} .\left(\mathrm{H}_{2} \mathrm{O}\right)_{2}: \mathrm{Cu} 9.94 \%, \mathrm{H}_{2} \mathrm{O}$ $5.63 \%$. Found: $\mathrm{Cu} 10.09 \%$, H2O 6.91\%.

\subsubsection{Synthesis of $\mathrm{Ni}(\text { metha- } \mathrm{L})_{2} .\left(\mathrm{H}_{2} \mathrm{O}\right)_{2}(\mathbf{5 d})$}

Compound $\mathbf{5} \mathbf{d}$ was synthesized according to general procedure of the complexes.

After the cooling at the room temperature, the light blue crystals were filtered off, washed with water and dried in air; 0.44 g Yield: (14\%). IR ( $\left.\mathrm{KBr}, \mathrm{cm}^{-1}\right): 3398$ (m, vo-H), 1514 (vs, vC=N), 1543 (s, vC=N),

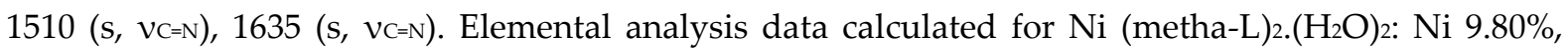
Found: Ni $10.09 \%$.

\subsubsection{Synthesis of $\mathrm{Ni}(\text { para- } \mathrm{L})_{2} .\left(\mathrm{H}_{2} \mathrm{O}\right)_{2}(5 \mathbf{e})$}

Compound 5e was synthesized according to general procedure of the complexes.

After the cooling at the room temperature, the cream crystals were filtered off, washed with water and dried in air; 0.67 g Yield: (21\%). IR (KBr, cm $\left.{ }^{-1}\right): 3422$ (m, vo-H), $1510\left(\mathrm{~m}, v_{\mathrm{c}=\mathrm{N}}\right), 1543\left(\mathrm{~m}, \mathrm{vc}_{\mathrm{C}}\right), 1558$ $\left(\mathrm{m}, v_{\mathrm{c}=\mathrm{N}}\right)$. Elemental analysis data calculated for $\mathrm{Ni}$ (metha- $\left.\mathrm{L}\right)_{2} .\left(\mathrm{H}_{2} \mathrm{O}\right)_{2}$ : Ni $9.80 \%$, Found: $\mathrm{Ni} 10.50 \%$.

\section{Results and Discussion}

\subsection{Synthesis}

Five new ligands able to generate complexes have been synthesized (Scheme 1).

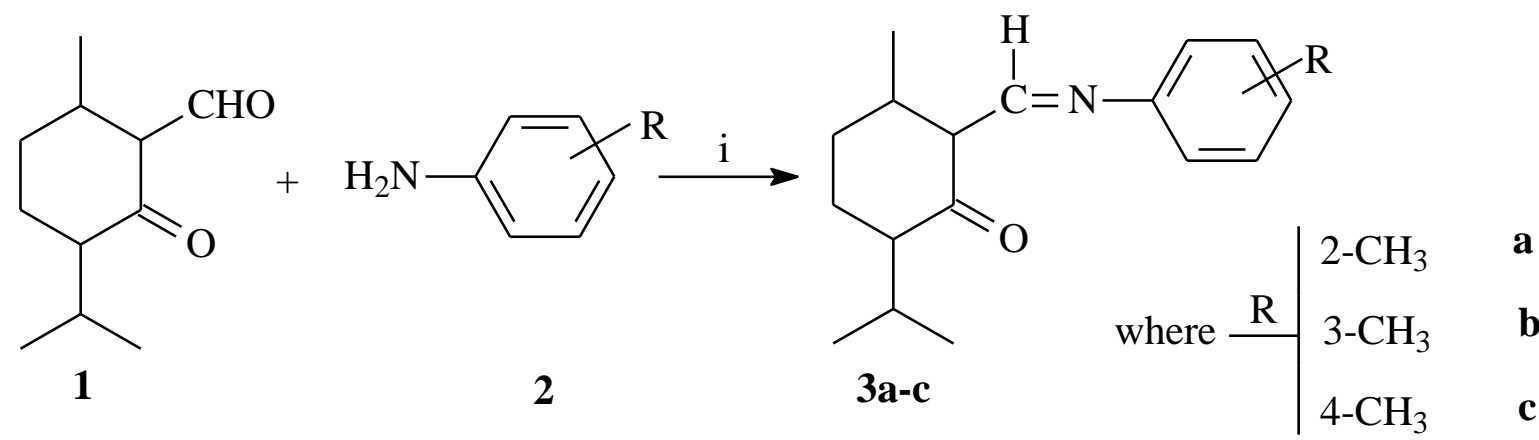


Scheme 1. Synthesis of Schiff bases. Reagents and conditions: $\mathrm{CH}_{3} \mathrm{OH}$, warm (i)

The presence of the $>\mathrm{C}=\mathrm{O}$ and $>\mathrm{C}=\mathrm{N}$ - groups respect to each other favours keto-enolic tautomerism (Scheme 2). This tautomerism has been attributed to an intramolecular hydrogen bond and might explain their chelating ability. NMR studies have shown that such Schiff bases with the carbonyl and azomethine groups exist in solution as the enolic tautomer (4a-c) and that the tautomer distribution was solvent dependent (Scheme 2) $[8,9]$.<smiles>[R]CC(C)C1C(=O)C(C(C)C)CCC1C=Nc1ccccc1</smiles>

3a-c<smiles>[R]Cc1cccc(N/C(NNc2ccccc2)=C2/C(=O)C(C(C)C)CCC2C)c1</smiles><smiles>[R]Cc1ccc(N/C=C2/C(=O)C(C(C)C)CCC2C)cc1</smiles><smiles>[R]CC(C)C1CCC(C)C2=C1O[TlH]N=C2c1ccccc1</smiles>

\section{Scheme 2. Tautomeric forms.}

\subsection{Elemental Analyses}

The elemental analyses are consistent with their formulation as anhydrous, monomeric Schiff bases chelates CuL2 and NiL2) or hydrated, monomeric complexes with water molecules either as coordinated or as crystalline water. All the metal chelates are colored, readily soluble in organic solvents (chloroform, acetone, methanol), but sparingly soluble in water.

\subsection{Thermodifferential Analysis}

The thermodifferential analysis are consistent with their formulation as anhydrous, monomeric Schiff bases chelates. Curves for compounds $\mathrm{Cu}$ (para- $\mathrm{L})_{2} \cdot\left(\mathrm{H}_{2} \mathrm{O}\right)_{2}$ and $\mathrm{Ni}(\text { para- } \mathrm{L})_{2}$ arc shown in detail in Figures $1 \mathrm{a}$ and $\mathbf{l} \mathbf{b}$. 


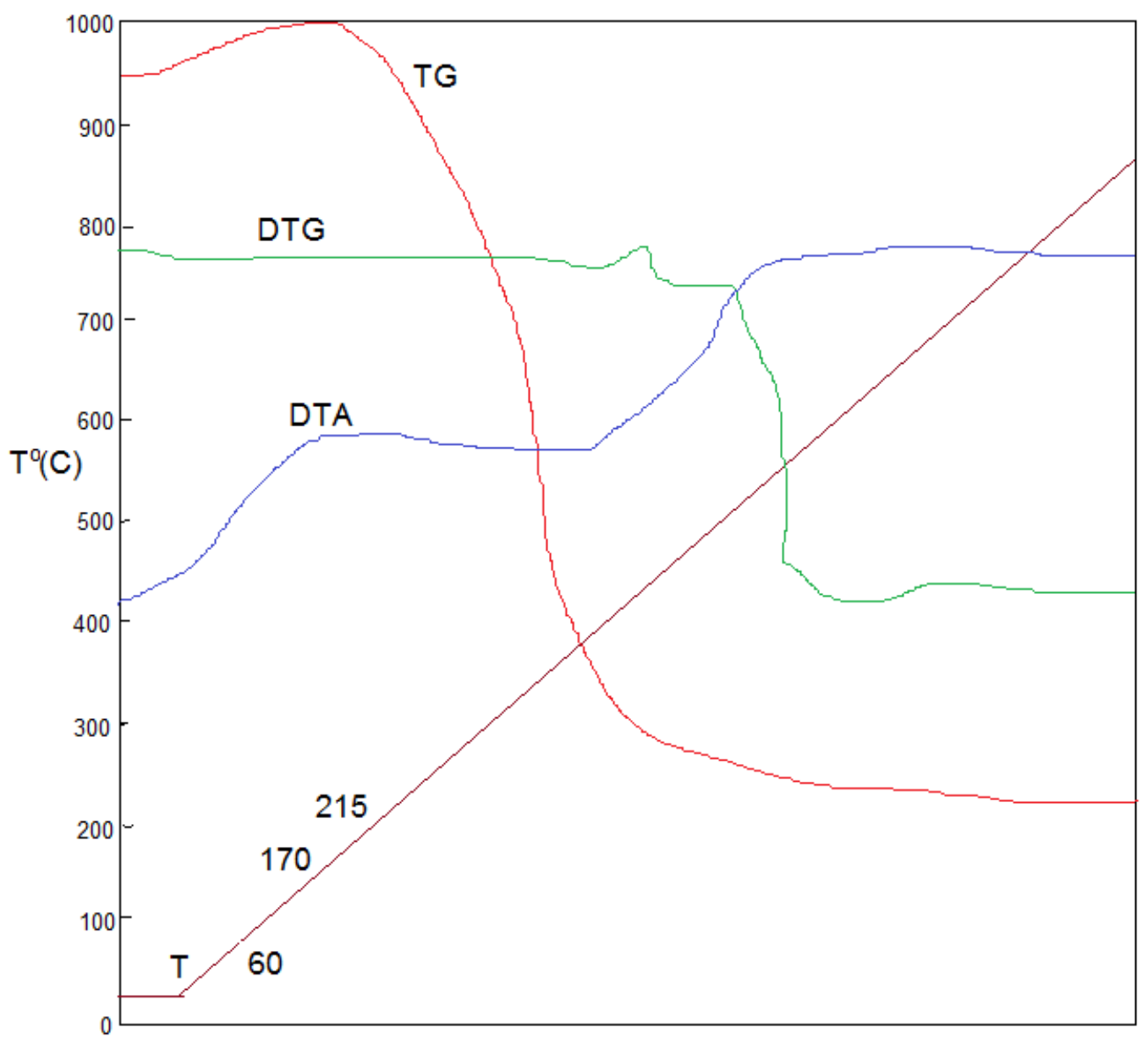

Figure 1a. Thermodifferntial curve of $\mathrm{Cu}\left(\right.$ para- $-\mathrm{L}_{2} 2 \mathrm{H}_{2} \mathrm{O}$ 


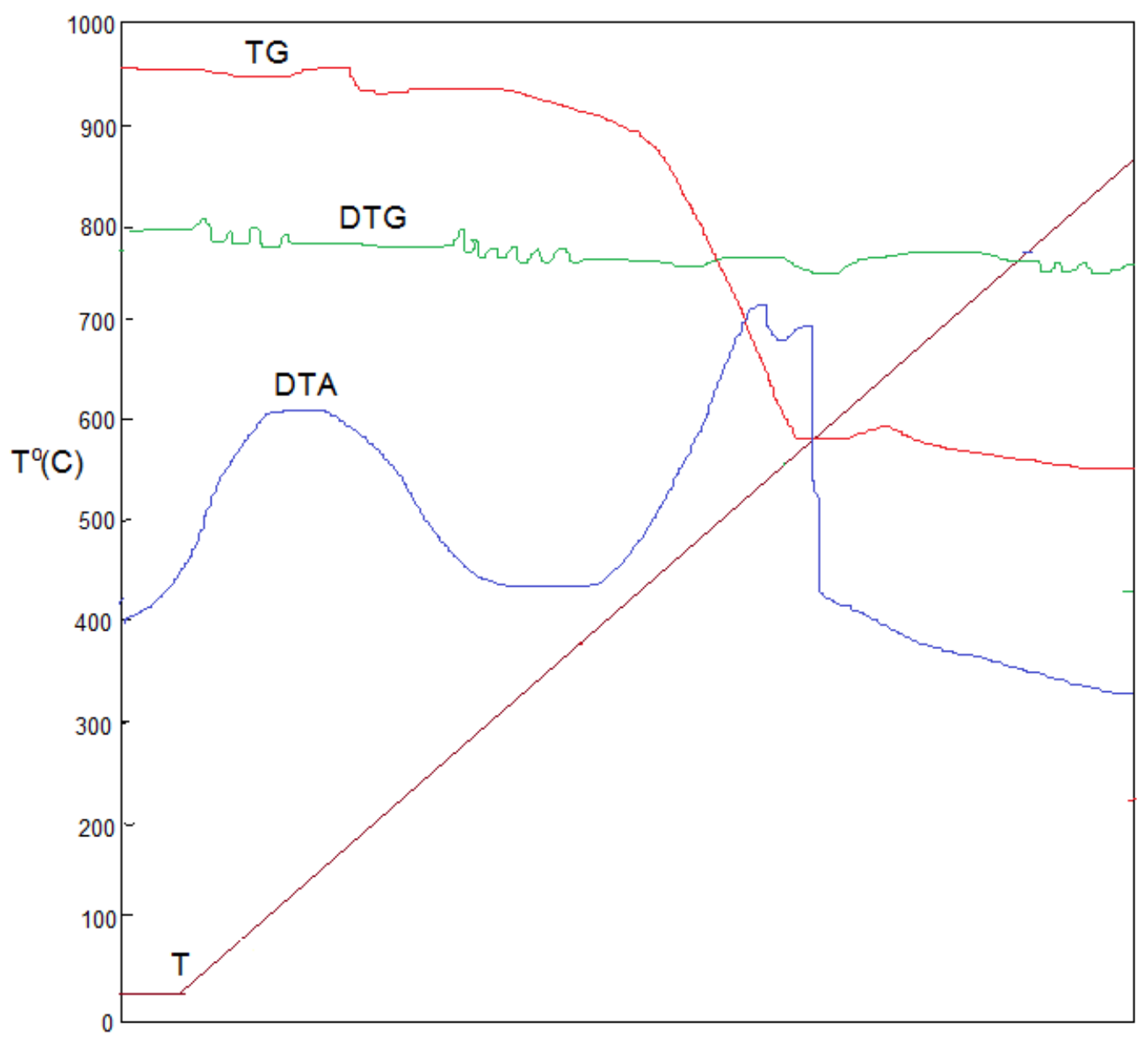

Figure 1b. Thermodifferntial curve of $\mathrm{Ni}(\text { para- } \mathrm{L})_{2} 2 \mathrm{H}_{2} \mathrm{O}$

For compound $\mathrm{Cu}$ (para- $\mathrm{L})_{2}$. $\left(\mathrm{H}_{2} \mathrm{O}\right)$ (Figure la) the mass loss observed within $60-215^{\circ} \mathrm{C}$ range in the TG curve corresponds to the loss of two water molecules per molecule of each copper compound. The TG curve shows that the water molecules are liberated in two steps (weight loss at $170^{\circ} \mathrm{C}$, found: $2.98 \%$, calcd., for $\mathrm{H}_{2} \mathrm{O}: 2.88 \%$; weight loss at $215^{\circ} \mathrm{C}$, found: $7.03 \%$, calcd., for $2 \mathrm{H}_{2} \mathrm{O}: 5.76 \%$ ). Hence, the two water molecules are present as coordinated water, in $\mathrm{Cu}(11)$ complexes.

The results indicate that compound $\mathrm{Ni}(\text { para- } \mathrm{L})_{2}$ (Figure $\mathbf{1 b}$ ) is stable up to $150^{\circ} \mathrm{C}$, but rapidly looses ligands at $565^{\circ} \mathrm{C}$ (weight loss at $565^{\circ} \mathrm{C}$, found: $88.86 \%$, calcd, for $2 \mathrm{~L}: .90 .14 \%$ ).

3.4. Electronic diffuse reflectance

The electronic diffuse reflectance spectra of the complexes are given in Figures $\mathbf{2}$ and 3.

The spectra of the Ni (1l) complexes (5d and $\mathbf{5 e}$, Figures 2 ) are like and are consistent with tetrahedral Ni (1l) complexes [10]. 


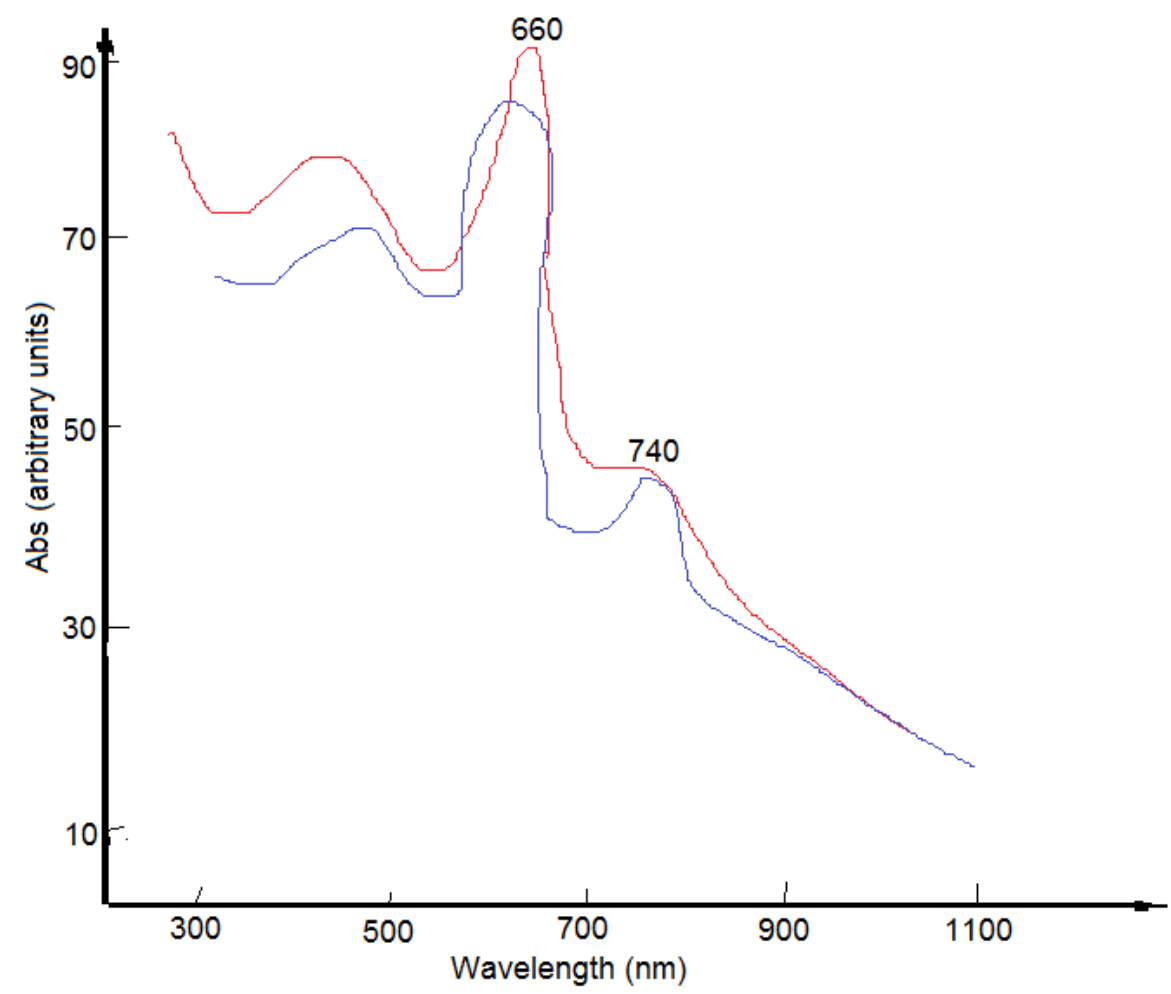

Figure 2. Electronic diffuse reflectance spectra of $\mathrm{Ni}($ meta-L)2 blue and $\mathrm{Ni}$ (para-L)2 red

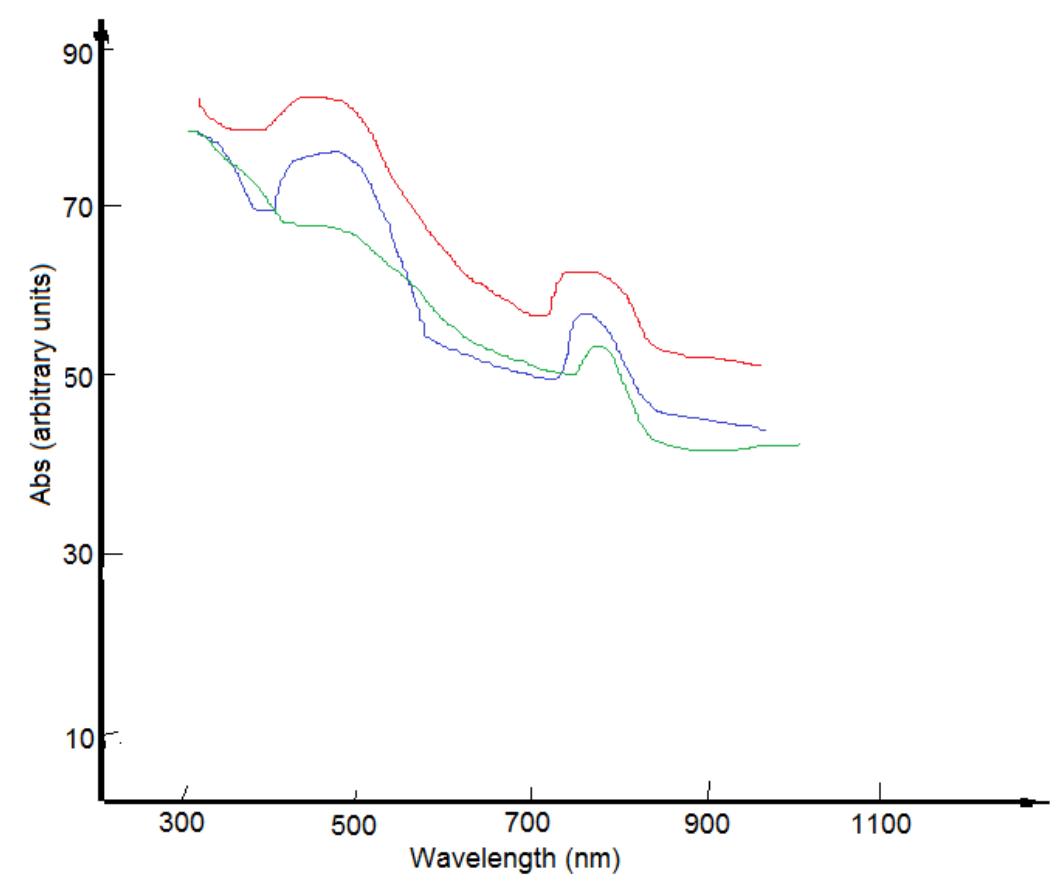

Figure 3. Electronic diffuse reflectance spectra of $\mathrm{Cu}$ (ortho-L)2 green;

$\mathrm{Cu}($ meta-L)2 blue and $\mathrm{Cu}($ para-L)2 red 
The spectra present the band $v_{3}(660 \mathrm{~nm})$ assignable to the ${ }^{3} \mathrm{~T} 1(\mathrm{P}){ }^{3}{ }^{3} \mathrm{~T} 1$ transition weak band $(760$ $\mathrm{nm}$, compound $\mathrm{Ni}$ (meta-L)2) or the shoulder (760 nm, compound Ni (para-L)2) are assigned as spin forbidden transitions to components of $1 \mathrm{D}$ levels [10]. The band $v_{1}$ assignable ${ }^{3} \mathrm{~T}_{2}-{ }^{3} \mathrm{~T}_{1}$ transition (near $500 \mathrm{~nm}$ ) is covered by a broad and intense band due to the ligands (500 nm). It is present in the spectra of the copper complexes, also. The spectra of the copper complexes $(\mathrm{Cu} \text { (ortho- } \mathrm{L})_{2} \cdot\left(\mathrm{H}_{2} \mathrm{O}\right)_{2}, \mathrm{Cu}(\mathrm{meta}-$ $\mathrm{L})_{2} .\left(\mathrm{H}_{2} \mathrm{O}\right)_{2}, \mathrm{Cu}$ (para- $\left.\mathrm{L}\right)_{2} .\left(\mathrm{H}_{2} \mathrm{O}\right)_{2}$ in Figure 3 are similar and present a band at $800 \mathrm{~nm}$ that could be assigned to a $d-d$ transition associated with a distorted octahedron [11-13].

\subsection{EPR spectra}

$E P R$ spectra of the three copper complexes recorded at room temperature on polycrystalline samples present a similar intense EPR signal characteristic monomeric species of $\mathrm{Cu}$ (ll) ion with a third order anisotropy for the factor $g$ resulting from distortion of octahedral geometry (Figure 4).

This anisotropy is compatible with $\mathrm{Cu}$ (11) ion in a compressed rhombic-octahedral geometry [12, 13] with $R>1$ and supports the electronic spectra. In a three $g$ value spectrum with $g_{1}<g_{2}<g_{3}$, the value of $\mathrm{R}=\left(\mathrm{g}_{2}-\mathrm{g}_{1}\right) /\left(\mathrm{g}_{3}-\mathrm{g}_{2}\right)$ may be significant: if $\mathrm{R}>1$, a predominant $\mathrm{dz}^{2}$ ground state is present and would be consistent with compressed axial or rhombic symmetry with slight misalignment of the axex. If $\mathrm{R}<$ 1 , a predominant $\mathrm{dx}^{2}-\mathrm{y}^{2}$ state is present $[12,13]$.

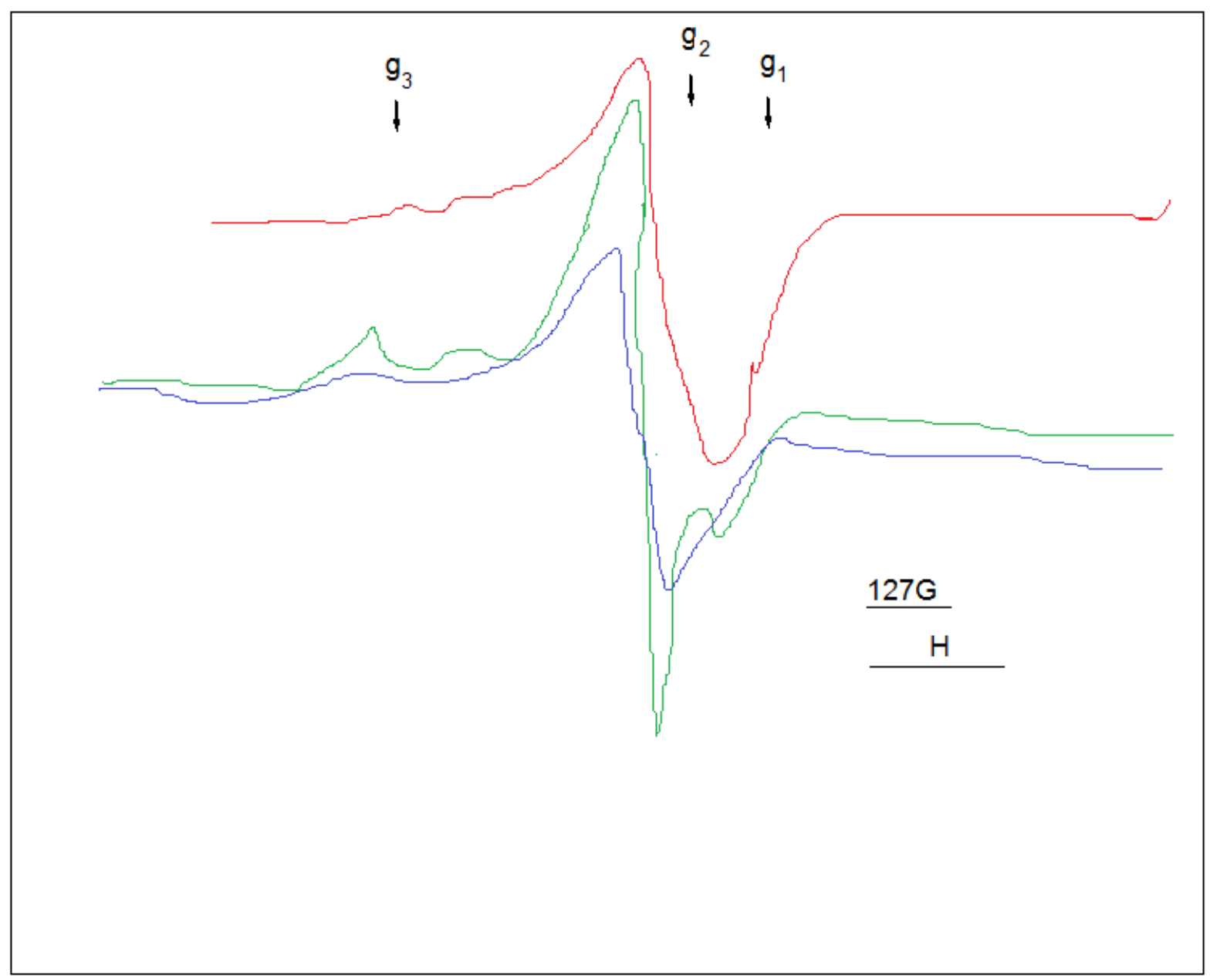

Figure 4. EPR spectra and SPR spectral parameters of $\mathrm{Cu}(\text { ortho-L })_{2}$ green; $\mathrm{Cu}(\text { meta- } \mathrm{L})_{2}$ blue and $\mathrm{Cu}(\text { para- } \mathrm{L})_{2}$ red 


$\begin{array}{llll}\text { Complex } & \mathrm{g}_{1} & \mathrm{~g}_{2} & \mathrm{~g}_{3} \\ \mathrm{Cu}(\text { ortho- } \mathrm{L})_{2} & 1.9804 & 2.0439 & 2.4586 \\ \mathrm{Cu}(\text { meta- } \mathrm{L})_{2} & 1.9804 & 2.0605 & 2.4586 \\ \mathrm{Cu}(\text { para-L })_{2} & 1.9959 & 2.0605 & 2.4466\end{array}$

\subsection{IR spectra}

The keto-enolic tautomerism is supported by presence of the bands due to $v \mathrm{O}-\mathrm{H}$ and $v \mathrm{C}=\mathrm{N}$. The band due to $v \mathrm{C}=\mathrm{O}(1700 \mathrm{~cm}-1)$ occurs as a very weak band or a shoulder. The band due to $v \mathrm{O}-\mathrm{H}$ occurs as a broad band (3200-3600 cm-1 range) with two unresolved peaks. The band due to $\mathrm{vC}=\mathrm{N}$ occurs as a broad band (1500-1600 cm-1 range) with three unresolved peaks.

A comparison of the position of the bands in spectra of the complexes with their position in the IR spectra of free ligands shows changes of the bands due to $v_{\mathrm{O}-\mathrm{H}}$ and $v_{\mathrm{C}=\mathrm{N}}$. Upon coordination, the stretching frequencies, $v_{\mathrm{C}=\mathrm{N}}$. are shifted to lower values and stretching frequencies $v \mathrm{O}-\mathrm{H}$ are shifted to higher values. These changes are generally noticed upon coordination of the Schiff bases containing an $\mathrm{N}$ and $\mathrm{O}$ donor atoms, by the both donor atoms [14]. The new band near $1111 \mathrm{~cm}-1$ occuring in the IR spectra of the three copper complexes only could be assigned to the coordinated water molecules in agreement with Fujita [15] and is be consistent with the results of the thermodifferential analysis.

\section{Results}

On the basis of elemental, differential analyses and spectral measurements, we conclude that $\mathrm{Cu}$ (1l) ion is hexacoordinated in a compressed rhombic geometry, while $\mathrm{Ni}$ (1l) ion is tetracoordinated in a tetrahedral geomety.

The ligands acted bidentately with both $\mathrm{O}$ and $\mathrm{N}$ donor atoms by deprotonation of the $\mathrm{OH}$ group making evident the participation of the ligands in the enolic tautomeric form.

$\mathrm{Cu}$ (1l) coordinates by atom donors, $\mathrm{N}$ and $\mathrm{O}$ in a plane and by shorter bonds to axial water molecules in a compressed rhombic geometry (Figure 5).

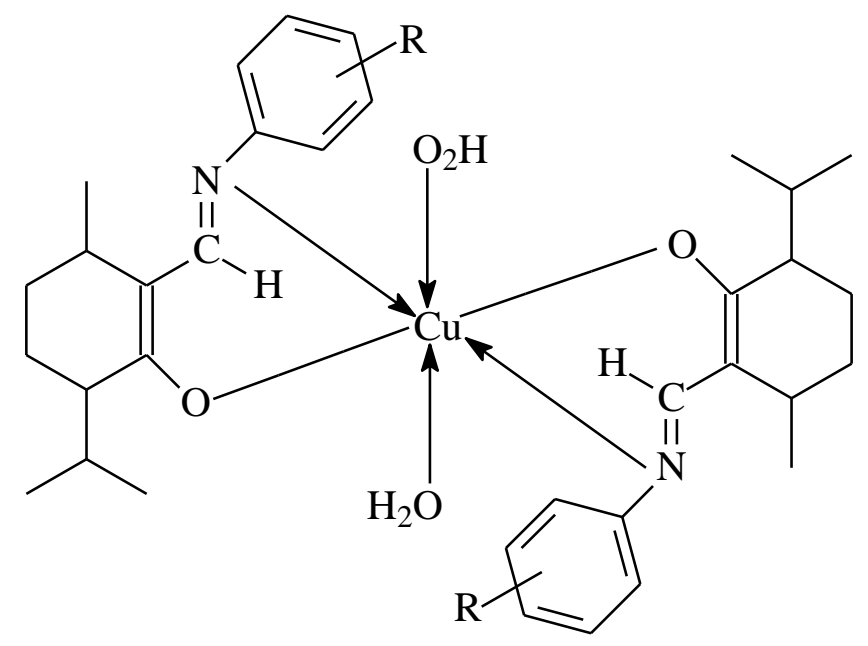

Figure 5. Structural formula proposed for the $\mathrm{Cu}$ (II)complexes 
The tetrahedral environment of the $\mathrm{Ni}$ (11) ion suggested by electronic spectra is obtained by both donor atoms, $\mathrm{N}$ and $\mathrm{O}$.

We may conclude that the metallic ion determines the type of the new complexes.

The arguments for the structure of the new chelates were fully supported by the spectral data (electronic, EPR and IR spectra).

\section{References}

1. Koziol, A.; K.Macegoniuk, E. G.; Grabowiecka, A.; Lochynski, S. Synthesis of nitrogencontaining monoterpenoids with antibacterial activity. Natural Product Research 2020, 34 (8), 10741079. [CrossRef] [PubMed]

2. Kahnt, M.; Heller, L.;Grabandt, P.; Al-Harrasi, A.; Csuk, R.; Platanic acid: a new scaffold for the synthesis of cytotoxic agents. Eur J Med Chem. 2018, 143, 59-265. [CrossRef] [PubMed]

3. Hertiani, T.; Edrada-Ebel, R., Ortlepp; S.; Van Soest, R.W.M.; De Voogd, N.J.; Wray, V.; Hentschel, U.; Kozytska, S.; Müller, W.E.G., Proksch, P. From anti-fouling to biofilm inhibition: new cytotoxic secondary metabolites from two Indonesian Agelas sponges. Bioorg Med. Chem. 2010, 18(3), 1297-1311. [CrossRef] [PubMed]

4. Grishko, V.V.; Galaiko, N.V.; Tolmacheva, I.A.; Kucherov, I.I.; Eremin, V.F.; Boreko, E.I; Savinova, O.V.; Slepukhin, P.A.; Functionalization, cyclization and antiviral activity of Asecotriterpenoids. Eur J Med Chem. 2014, 83, 601-608. [CrossRef] [PubMed]

5. Jain, J.S.; Srivastava, R.S.; Agggarwal, N.; Sinha, R. Synthesis and Evaluation of Schiff Bases for Anticonvulsant and Behavioral Depressant Properties, Central Nervous System Agents in Medicinal Chemistry 2007, 7(3), 200-204. [CrossRef] [PubMed]

6. Jain, J.; Kumar, Y.; Sinha, R.; Kumar, R.; Stables, J. Menthone Aryl Acid Hydrazones: A New Class of Anticonvulsants. Medicinal Chemistry 2011, 7(1), 56-61. [CrossRef] [PubMed]

7. Ciobanu, A.; Zalaru F.; Zalaru, C.; Dumitrascu, F.; Draghici, C. Coordination compounds of $\mathrm{Cu}(\mathrm{II})$ with schiff bases derived from formylmenthone and aromatic amines. Acta Chimica Slovenica, 2003, 50(3), 441-450. [CrossRef] [PubMed]

8. Dudek, G.O. Nuclear Magnetic Resonance Studies of Keto-Enol Equilibria. IV. Naphthalene Derivatives. J.Am.Chem.Soc. 1963, 85(6), 694- 697. [CrossRef] [PubMed]

9. Dudek, G.O.; Dudek, E.P. Spectroscopic Studies of Keto-Enol Equilibria. VII. Nitrogen-15 Substituted Schiff Bases. J. Am. Chem. Soc. 1964, 86 (20), 4283-4287. 2697 [CrossRef] [PubMed]

10. Lever, A.B.P. "Inorganic Electronic Spectroscopy", Elsevier, Amsterdam, 1968, 182.

11. Enamullah, M.; Zaman, M.M.; Bindu, M.M.; Islam, M.K.; Islam, M.A. Experimental and theoretical studies on isatin-Schiff bases and their copper(II)-complexes: Syntheses, spectroscopy, tautomerism, redox potentials, EPR, PXRD and DFT/TDDFT. J. Molec. Struct. 2020, 1201, 127207. 
12. Hathaway, B.J.; Billing, The electronic properties and stereochemistry of mono-nuclear complexes of the copper(II) ion Coord. Chem.Rev. 1970, 5(2), 143-207. [CrossRef] [PubMed]

13. Mandlik, K.K. Synthesis, characterization and thermal studies of Schiff base complexes of $\mathrm{Co}(\mathrm{II}), \mathrm{Ni}(\mathrm{II}), \mathrm{Cu}(\mathrm{II}), \mathrm{Zn}(\mathrm{II}), \mathrm{Cr}(\mathrm{III}), \mathrm{Fe}(\mathrm{III}), \mathrm{Mn}(\mathrm{III}), \mathrm{Vo}(\mathrm{IV})$ and $\mathrm{Zr}(\mathrm{IV})$ International Journal of ChemTech Research, 2013, 5(1), 362-366 [CrossRef] [PubMed]

14. Percy, G.C.; Thortnton, D.A. Infrared spectra of N-aryl Schiff base complexes J. Inorg.Nucl.Chem. 1971, 7(7), 599-604. CrossRef] [PubMed]

15. Fujita, J.; Nakamato, K. Kobayshi, M. Infrared Spectra of Metallic Complexes. II. The Absorption Bands of Coördinated Water in Aquo Complexes. J. Am. Chem. Soc. 1956, 78(16), 39633965. [CrossRef] [PubMed] 